\title{
The Correlation of Palladium Supported Carbon (Pd/C) Loading and Optimum Nafion Ionomer Weight Percent (wt.\%) Content in the PEM Fuel Cell Catalyst Layer
}

\author{
${ }^{1}$ Abdulhamed A. Sghayer, ${ }^{2}$ Adel Diyaf, ${ }^{3}$ Khaled A. Mazuz, \\ and ${ }^{4}$ Naji A. Issa \\ ${ }^{1,2,3}$ Department of Physics, Faculty of Science, University of Tripoli, \\ Tripoli-Libya. \\ ${ }^{4}$ Department Mechanical Engineering, Faculty of Engineering, \\ University of Benghazi, Benghazi -Libya.
}

e-mail: ${ }^{*}$ abdulsghayer@yahoo.co.uk, ${ }^{2}$ Adeldiyaf@yahoo.com, ${ }^{3}$ kmazuza@gmail.com, ${ }^{4}$ alsahabi2014@gmail.com

\begin{abstract}
The presence of Nafion ionomer as one of basic elements in the PEM fuel cell catalyst layer structure can extend the three phase contact between the reactant gases, electrolyte and the catalyst surface and make the catalyst layer active in three dimensions, since the proton can move throughout the entire catalyst layer, which would improve the PEM fuel cell performance. The main objective of this study is to examine the dependence of the optimum Nafion ionomer weight percent (wt.\%), on the palladium supported carbon $(\mathrm{Pd} / \mathrm{C})$ loading in PEM fuel cell catalyst layer. The results showed that the optimum Nafion ionomer contents in the PEM fuel cell catalyst layer is dependent and inversely proportional to the amount of Pd/C loading. For catalyst layers with a Palladium supported carbon (Pd/C) loading of $4.0 \pm 0.1 \mathrm{mg} / \mathrm{cm}^{2}, 3.2 \pm 0.1 \mathrm{mg} / \mathrm{cm}^{2}$, and $2.45 \pm 0.05 \mathrm{mg} / \mathrm{cm}^{2}$, the best performance was obtained at about 33, 35, and $37 \mathrm{wt} . \%$ Nafion ionomer loading respectively.
\end{abstract}

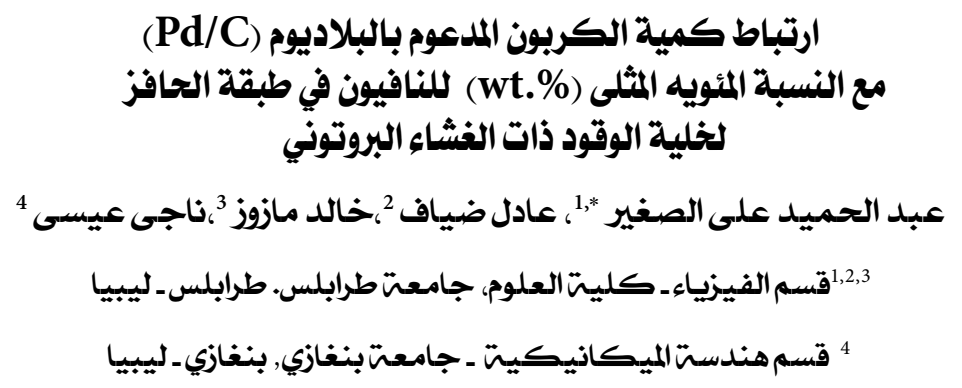

* Corresponding author 


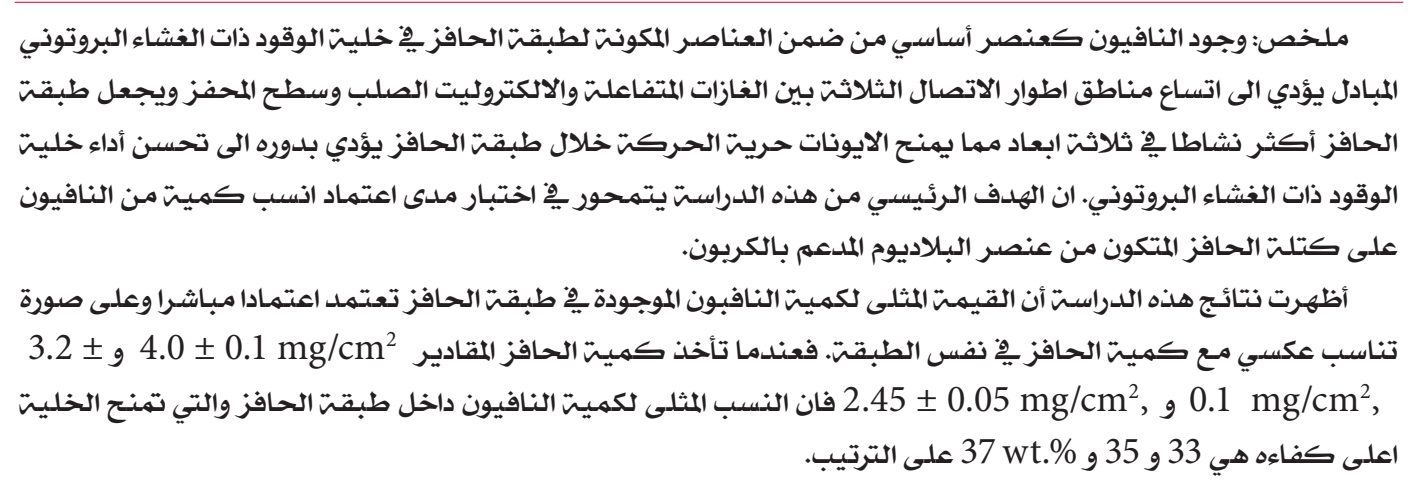

Keywords: PEM fuel cells, catalyst layer Performance, Nafion Ionomer, Polarization Curve, Renewable Energy

This is an open access article under the CC BY-NC license (http://Attribution-NonCommercial 4.0 (CC BY-NC 4.0)).

\section{INTRODUCTION}

Proton exchange membrane fuel cells (PEMFCs) are promising energy converters, especially in automobile applications, due to their high power density, zero emissions, rapid cold start-up, and system robustness [1-4]. Among the PEM fuel cell components, the catalyst layer (CL) is one of the most important component to achieve a high

performance with reducing costs and long lifetime of the PEM fuel cell. The synthesis of CLs has attracted a great deal of attention in terms of optimization to satisfy the twin demands of high performance and reduced costs. This component (CL) is a porous composite structure of carbon (electronically conductive), recast Nafion ionomer in order to provide a pathway for proton transport from the catalyst nanoparticle to the PEM. (transporting proton) and catalytic sites to promote the electrochemical reactions. Optimization of the Nafion ionomer content is essential step for production of high performance catalyst layer [5-13]. It's necessary to minimize ohmic and mass transport overpotentials in the catalyst layer. Very low Nafion ionomer results in poor contact of the membrane electrolyte with the catalyst layer and hence poor catalyst layer performance. Too high a concentration of Nafion ionomer causes reduction of catalyst layer performance due to blocking of the catalyst sites, blocking of the catalyst layer pores, reduction of gas permeability and increased mass transfer overpotential. Many related studies have been reported on the effect of Nafion ionomer content in the PEM fuel cell electrode performance [14-22]. Different researchers suggested that the different optimal Nafion ionomer loadings in the electrodes they studied were due to either the catalyst type [14-18] or the pretreatment conditions [19-28]. Even though most of the researchers provided test results based on the same commercial catalyst (20\% Pt/Vulcan XC-72) [29-36,11], the electrodes providing the best cell performance and the highest power density comprised different optimal Nafion loadings. This paper aims to investigate the dependence of an optimum Nafion ionomer wt.\% to the palladium loading in the PEM fuel cell catalyst layer prepared by the decals process using $30 \%$ Palladium supported on carbon catalyst (Pd/C) and Nafion ionomers solution of EW 1000.

\section{EXPERIMENTAL.}

\subsection{Membrane Pre-treatment}

Before being used in the membrane electrode assembly (MEA), the polymer electrolyte membranes made of Nafion 1035 (Sigma-Aldrich UK, $89 \mathrm{~mm}$ thickness, and $1000 \mathrm{EW}$ ) with a $3 \mathrm{~cm}$ diameter, were 
washed in various solutions to remove trace organic and inorganic contaminants and to change their form. The pre-treatment procedure involved boiling the polymer electrolyte membrane in 3 wt.\% aqueous $\mathrm{H}_{2} \mathrm{O}_{2}$ solutions for $1 \mathrm{~h}$ at $85-90^{\circ} \mathrm{C}$, followed by boiling for $1 \mathrm{~h}$ in deionised water at $85-90{ }^{\circ} \mathrm{C}$, and subsequently boiling for a further $1 \mathrm{~h}$ in a fresh sample of deionised water. The membrane was then boiled for $1 \mathrm{~h}$ in $0.5 \mathrm{M}$ $\mathrm{H}_{2} \mathrm{SO}_{4}$ to get a fully $\mathrm{H}^{+}$-form exchanged membrane. After that, the membrane was boiled for $15 \mathrm{~min}$. in pure water at temperature $85-90{ }^{\circ} \mathrm{C}$ to remove the remaining $\mathrm{H}_{2} \mathrm{SO}_{4}$ on the surface of the membrane, followed by storing in fresh deionised water until use.

\subsection{Catalyst Layers Preparation}

All of the catalyst layers were prepared in-house by the decals process, with some modifications [7]. The catalyst ink was prepared by using of $30 \%$ Palladium supported on carbon catalyst (Pd/C) (supplied by Sigma-Aldrich), and Nafion 20 wt.\% solution (EW 1000, supplied by Sigma-Aldrich), diluted to 10 wt.\% in (25\% water, $37.5 \%$ ethanol, and $37.5 \%$ 1-propanol). Catalyst mixtures were prepared in the following way: $4.0 \pm 0.1 \mathrm{mg} / \mathrm{cm}^{2}$ of $30 \% \mathrm{Pd} / \mathrm{C}$ was wetted with a few drops of deionised water, and stirred for $10 \mathrm{~min}$. After stirring, the required volume of $20 \mathrm{wt} . \%$ Nafion ionomer solution was added to the mixture and stirred for $30 \mathrm{~min}$, followed by ultrasonication for $1 \mathrm{~h}$. After ultrsonication process, the mixture was kept under stirring overnight to achieve a homogenous ink. The Nafion ionomer loading and the catalyst loading in the catalyst layer can be adjusted, according to the requirements of the parametric study [7]. The formed catalyst ink was brush painted onto a $3.14 \mathrm{~cm}^{2}$ Teflon discs. After painting the decals were left into dry air at room temperature for $30 \mathrm{~min}$., and then weighed. The process of painting and drying was repeated until the desired catalyst loading was reached.

\subsection{Membrane Electrode Assembly (MEA)}

The membrane-electrode assembly (MEA) was prepared by placing catalyst layers at both sides of the pretreated Nafion 1035 membrane, followed by hot-pressing at $140 \bowtie \mathrm{C}$ and $200 \mathrm{~atm}$ for $3 \mathrm{~min}$. The formed MEA's were then hydrated by boiling them in $0.5 \mathrm{M} \mathrm{H} 2 \mathrm{SO} 4$ for $1 \mathrm{~h}$, followed by boiling in pure deionised water for 10 min., with excess water subsequently being removed. Finally, the MEA's were placed between two glass strips, which kept it flat while slowly drying prior to use.

\subsection{Fuel cell Assembly and Performance Measurements.}

PEM fuel cell was assembled by placing the MEA in a single cell test fixture (Electrochem Inc., USA) and connected to fuel cell test station (Nara Cell Tech Corp., Korea) provided with gas humidifier, mass flow controller, temperature indicator-controller etc. The current-voltage (i-V) characteristics of the cell was evaluated, using hydrogen and oxygen reactants at 1 atm, at $85^{\circ} \mathrm{C}$ using HPCS1 high power potentiostat/ galvanostat along with WBCS3000 battery cycler system (WonA Tech., Korea).

\section{RESULTS AND DISCUSSION}

PEM Fuel cell catalyst layers with a $30 \%$ Palladium supported carbon $(30 \% \mathrm{Pd} / \mathrm{C})$ loading of $4.0 \pm 0.1 \mathrm{mg} /$ $\mathrm{cm} 2$, and $3.2 \pm 0.1 \mathrm{mg} / \mathrm{cm}^{2}$, and $2.45 \pm 0.05 \mathrm{mg} / \mathrm{cm}^{2}$ were prepared with different Nafion ionomer (EW 1000) weight percentage (wt.\%) in the catalyst layer. The PEM fuel cell performance was evaluated at $85{ }^{\circ} \mathrm{C}$, with humidified hydrogen-oxygen reactants, at 1 atm pressure. Figure 1, shows the current-voltage (i-V) characteristics of the catalyst layer with $\mathrm{Pd} / \mathrm{C}$ of $4.0 \pm 0.1 \mathrm{mg} / \mathrm{cm} 2$ and different Nafion ionomer contents, ranging from 20 to $40 \mathrm{wt} . \%$. The catalyst layer performance is low at $20 \mathrm{wt} . \%$ Nafion content. The PEM fuel cell performance improved with an increase in the Nafion ionomer content from 20 to $33 \mathrm{wt} . \%$. 


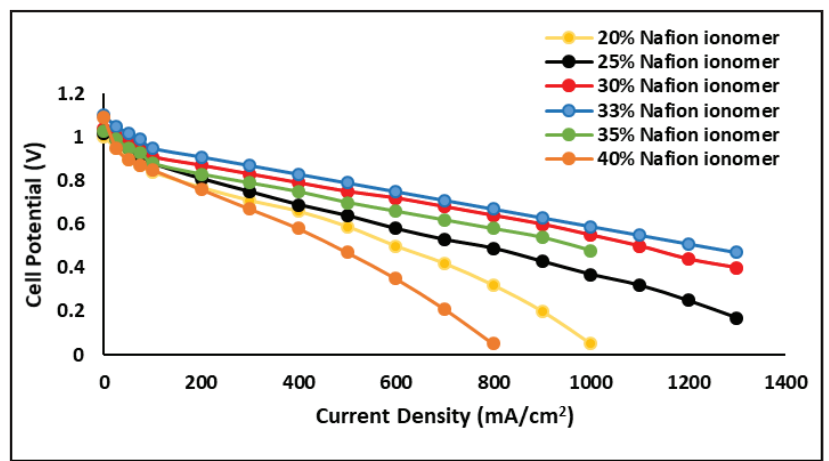

Figure (1). the current-voltage (i-V) characteristics of the catalyst layer with $30 \% \mathrm{Pd} / \mathrm{C}$ of $4.0 \pm 0.1 \mathrm{mg} / \mathrm{cm}^{2}$ and different Nafion ionomer contents, ranging from 20 to $40 \mathrm{wt} . \%$, with humidified hydrogenoxygen reactants at $85^{\circ} \mathrm{C}$, temperature and, 1 atm pressure.

This was expected since the application of Nafion to the catalyst layer improves the proton transport between the catalyst layer surface and the membrane. The protonic conductivity of such a catalyst layer is proportional to the amount of Nafion ionomer in the composition mixture. However, a slightly decrease in the PEM fuel cell potential with a little further increase in Nafion ionomer content to $35 \mathrm{wt} . \%$ was found. When Nafion ionomer was increased to $40 \mathrm{wt} \%$ in the catalyst layer, the PEM fuel cell potential decreased to the minimum $0.21 \mathrm{~V}$ at the same current density of $700 \mathrm{~mA} / \mathrm{cm}^{2}$. This behavior was due to the high Nafion ionomer concentration in the PEM fuel cell catalyst layer, which then blocked the catalyst sites, reducing the electronic conductivity, and gas permeability in the catalyst layer [6]. Therefore, the maximum catalyst layer performance was achieved at $33 \mathrm{wt}$. \% Nafion loading, and the minimum catalyst layer performance was observed at $40 \mathrm{wt}$ \% Nafion ionomer loading. In a similar way, the performance of the catalyst layers with $3.2 \pm 0.1 \mathrm{mg} / \mathrm{cm}^{2}$ catalyst loading was tested using a Nafion 1035 membrane, and the results are presented in Figure 2. The performance was found to increase as the Nafion ionomer content increased from 20 to $35 \mathrm{wt}$. $\%$. Further increase to $40 \mathrm{wt}$. \% Nafion ionomer loading leads to a decrease in catalyst layer performance. The best catalyst layer performance is obtained at $35 \mathrm{wt} . \%$ Nafion. Figure 3, shows the current-voltage $(i-\mathrm{V})$ characteristics of the catalyst layer with $\mathrm{Pd} / \mathrm{C}$ of $2.45 \pm 0.05 \mathrm{mg} / \mathrm{cm}^{2}$ and different Nafion ionomer contents, ranging from 20 to $45 \mathrm{wt} . \%$. The best catalyst layer performance is obtained at $38 \mathrm{wt}$. \% Nafion.

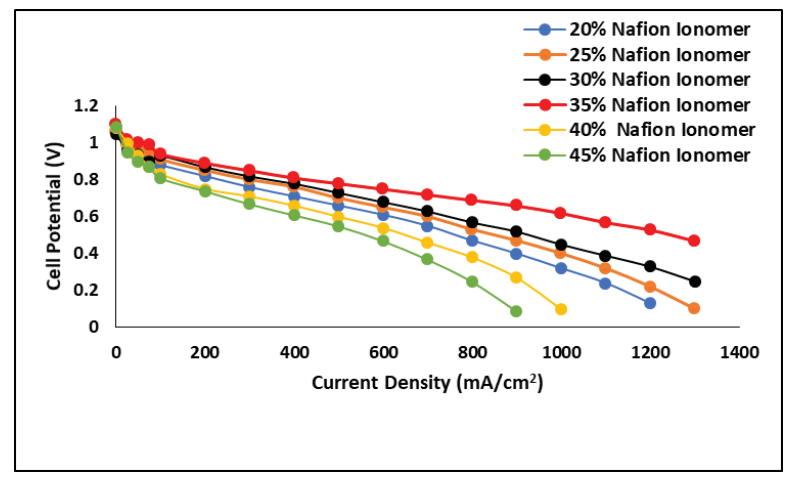

Figure (2). the current-voltage (i-V) characteristics of the catalyst layer with $30 \% \mathrm{Pd} / \mathrm{C}$ of $3.20 \pm 0.1 \mathrm{mg} / \mathrm{cm}^{2}$ and different Nafion ionomer contents, ranging from 20 to $45 \mathrm{wt} . \%$, with humidified hydrogenoxygen reactants at $85^{\circ} \mathrm{C}$, temperature and, 1 atm pressure

Figure 4, shows how the Nafion ionomer wt.\% correlates with Pd/C loadings for catalyst layers made using 
$30 \% \mathrm{Pd} / \mathrm{C}$. Large amount of the Nafion ionomer $37 \mathrm{wt} . \%$ was observed at $2.45 \pm 0.05 \mathrm{mg} / \mathrm{cm}^{2} \mathrm{Pd} / \mathrm{C}$ in the catalyst layer, and the low amount of Nafion ionomer which is needed to obtain the best PEM fuel cell catalyst layer performance was observed $33 \mathrm{wt} . \%$ when the $\mathrm{Pd} / \mathrm{C}$ loading is $4.0 \pm 0.1 \mathrm{mg} / \mathrm{cm}^{2}$.

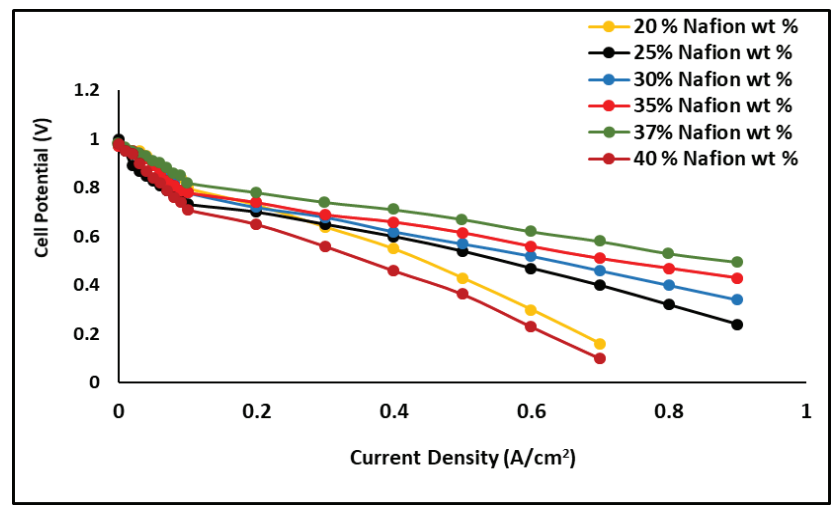

Figure (3). the current-voltage (i-V) characteristics of the catalyst layer with $\mathrm{Pd} / \mathrm{C}$ of $2.45 \pm 0.05 \mathrm{mg} / \mathrm{cm}^{2}$ and different Nafion ionomer contents, ranging from 20 to $45 \mathrm{wt}$.\%, with humidified hydrogen-oxygen reactants at $85{ }^{\circ} \mathrm{C}$, temperature and, 1 atm pressure.

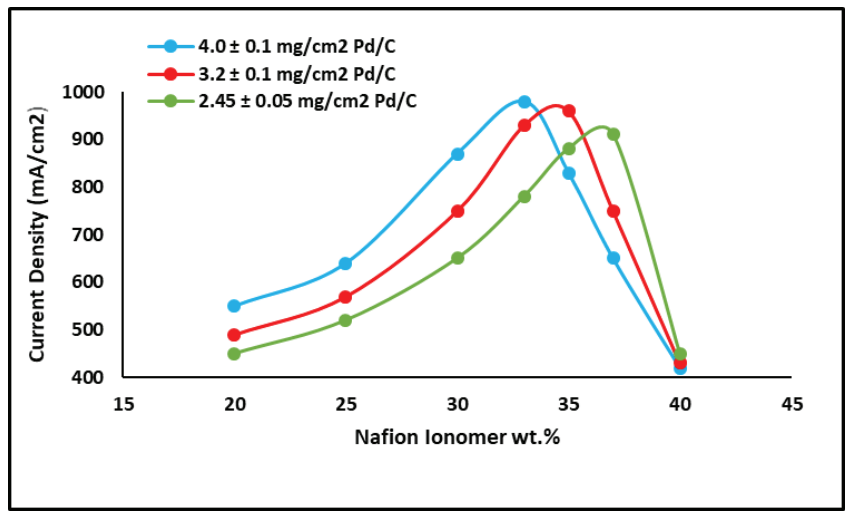

Figure (4). the effect of Nafion ionomer wt.\% content in the catalyst layer on PEM fuel cell performance.

\section{CONCLUSION}

Optimum amount of Nafion ionomer in the catalyst layer is required for good PEM fuel cell performance. The present study has established that the optimum Nafion ionomer content in the PEM fuel cell catalyst layer should depend on the amount of $\mathrm{Pd} / \mathrm{C}$ loading. The numerical values of the optimum amounts of Nafion may, however, depend on the fabrication method. It is also concluded that the optimum Nafion wt.\% in PEM fuel cell catalyst layers' is inversely proportional to the $\mathrm{Pd} / \mathrm{C}$. For catalyst layers with a Palladium supported carbon (Pd/C) loading of $4.0 \pm 0.1 \mathrm{mg} / \mathrm{cm} 2,3.2 \pm 0.1 \mathrm{mg} / \mathrm{cm} 2$, and $2.45 \pm 0.05 \mathrm{mg} / \mathrm{cm} 2$, the best performance was obtained at about 33,35 , and $37 \mathrm{wt} . \%$ Nafion ionomer loading respectively.

\section{REFERENCES}

[1]. S. Litster, and G. McLean: "PEM fuel cell electrodes", Journal of Power Sources, 130, (1-2), pp.61, 2004. 
[2]. S. Gottesfeld, and T. Zawodzinski, "Polymer electrolyte fuel cells", In Advanced Electrochemical Science and Engineering; Alkire, R.C. et al. (Eds.), Volume 5, Wiley-VCH, Germany pp. 195, 1997.

[3]. V. Mehta, and. J, S. Cooper: "Review and analysis of PEM fuel cell design and manufacturing", Journal of Power Sources, 114, (1), pp.32, 2003

[4]. M. Eikerling, A. Ioselevich, and. A Kornyshev.: "How good are the electrodes we use in PEFC?" Fuel Cells, 4, (3), pp. 131, 2004.

[5]. Z. Qi, and R. Kaufman: "Low Pt loading high performance cathodes for PEM fuel cells", Journal of Power Sources, 113, (1), pp. 37, 2003.

[6]. E. Passalacqua, F. Lufrano, G. Squadrito, A. Patti, and L. Giorgi: "Nafion content in the catalyst layer of polymer electrolyte fuel cells: effects on structure and performance", Electrochimica Acta, 46, (6), pp. 779, 2001.

[7]. G. Sasikumar, J.W. Ihm, and H. Ryu: "Optimum Nafion content in PEM fuel cell electrodes", Electrochimica Acta, 50, (2-3), pp. 601, 2004.

[8]. S. J. Lee, S. Mukerjee, J. McBreen, Y.W. Rho, Y.T. Kho, and T.H. Lee: "Effects of Nafion impregnation on performances of PEMFC electrodes", Electrochimica Acta, 43, (24), pp. 3693. 1998.

[9]. M.S. McGovern, E.C. Garnett, C. Rice, R.I Masel, and A. Wieckowski: "Effects of Nafion as a binding agent for unsupported nanoparticle catalysts", Journal of Power Sources 115, (1), pp. 35. 2003.

[10]. J.M. Song, S.Y. Cha, and. W.M. Lee: "Optimal composition of polymer electrolyte fuel cell electrodes determined by the AC impedance method”, Journal of Power Sources, 94, (1), pp. 78, 2001.

[11]. E. Antolini, L. Giorgi, A. Pozio, and E. Passalacqua: "Influence of Nafion loading in the catalyst layer of gas-diffusion electrodes for PEFC", Journal of Power Sources 77, (1), pp. 136, 1999.

[12]. Z. Xu, Z. Qi and A. Kaufman: "Advanced fuel cell catalysts", Electrochemical Solid-State Letters. 6, (9), 2003, p. A171

[13]. E. Bradley Easton, Z. Qi, A. Kaufman and P.G. Pickup: "Chemical modification of proton exchange membrane fuel cell catalysts with a sulfonated silane”, Electrochemical Solid-State Letters, 4, (5), 2001, p. A59.

[14]. T. Mittermeier, A. weib, H. A. Gastiger, and F. Hasché, "Monometallic Palladium for Oxygen Reduction in PEM Fuel Cells: Particle-Size Effect, Reaction Mechanism, and Voltage Cycling Stability”, Journal of The Electrochemical Society, 164, (12) pp. F1081, 2017.

[15]. X. He, Y. Xia, C. Liang, J. Zhang, H. Huang, Y. Gan, C. Zhao, W. Zhang, "A flexible non-precious metal Fe-N/C catalyst for highly efficient oxygen reduction reaction", Nanotechnology. 30, pp. 1361, 2019.

[16]. N. Guarrotxena, "Smart functional nanoscale-hybrid materials: Surface modification and applications", J. Mater. Sci. Eng. 06 (2017). doi:10.4172/2169-0022.C1.058.

[17]. Y. Wang, J. Roller, R. Maric, Novel flame synthesis of nanostructured $\alpha-\mathrm{Fe}_{2} \mathrm{O}_{3}$ electrode as high-performance anode for lithium ion batteries, J. Power Sources. 378, pp. 511, 2018.

[18]. Gisu Doo, Ji Hye Lee, Seongmin Yuk, Sungyu Choi, Dong-Hyun Lee, Dong Wook Lee, Hyun Gyu Kim, Sung Hyun Kwon, Seung Geol Lee, and Hee-Tak Kim: "Tuning the Ionomer Distribution in the Fuel Cell Catalyst Layer with Scaling the Ionomer Aggregate Size in Dispersion”, ACS Appl. Mater. Interfaces 10, 21, pp. 17835, 2018.

[19]. Nagappan Ramaswamy, Wenbin Gu, Joseph M. Ziegelbauer, and Swami Kumaraguru," Carbon Support Microstructure Impact on High Current Density Transport Resistances in PEMFC Cathode" Journal of The Electrochemical Society, (167) pp. 064515, 2020.

[20]. N. Ramaswamy and S. Kumaraguru, "Materials and design selection to improve high current density performance in PEMFC.” ECS Trans., 85, pp. 8352018.

[21]. F. C. Cetinbas, R. K. Ahluwalia, N. N. Kariuki, and D. J. Myers, "Agglomerates in polymer electrolyte fuel cell electrodes: part I. structural characterization.” J. Electrochem. Soc., 165, pp. F1051, 2018.

[22]. E. Padgett et al., "Mitigation of PEM fuel cell catalyst degradation with porous carbon supports." J. Electrochem. Soc., 166, pp. F198, 2019.

[23]. T. Morawietz et al., "High-resolution analysis of ionomer loss in catalytic layers after operation." J. Electrochem. Soc., 165, pp. F3139, 2018. 
[24]. Y.-C. Park, H. Tokiwa, K. Kakinuma, M. Watanabe, and M. Uchida, "Effects of carbon supports on Pt distribution, ionomer coverage and cathode performance for polymer electrolyte fuel cells." J. Power Sources, 315, pp.179 2016.

[25]. E. Padgett et al., "Mitigation of PEM fuel cell catalyst degradation with porous carbon supports." J. Electrochem. Soc., 166, pp. F198 2019.

[26]. X. Tuaev, S. Rudi, and P. Strasser, "The impact of the morphology of the carbon support on the activity and stability of nanoparticle fuel cell catalysts." Catal. Sci. Technol., 6, pp. 8276, 2016.

[27]. F. C. Cetinbas, R. K. Ahluwalia, N. N. Kariuki, and D. J. Myers, "Agglomerates in polymer electrolyte fuel cell electrodes: part I. structural characterization." J. Electrochem. Soc., 165, pp. F1051, 2018.

[28]. A. Ohma, K. Fushinobu, and K. Okazaki, "Influence of Nafion" film on oxygen reduction reaction and hydrogen peroxide formation on Pt electrode for proton exchange membrane fuel cell." Electrochim. Acta, 55, pp.8829, 2010.

[29]. X. Tuaev, S. Rudi, and P. Strasser, "The impact of the morphology of the carbon support on the activity and stability of nanoparticle fuel cell catalysts." Catal. Sci. Technol., 6, pp.8276, 2016.

[30]. H. Iden, T. Mashio, and A. Ohma, "Gas transport inside and outside carbon supports of catalyst layers for PEM fuel cells." J. Electroanal. Chem., 708, pp.87 2013.

[31]. G. Gadikota, B. Dazas, G. Rother, M. C. Cheshire, and I. C. Bourg, "Hydrophobic solvation of gases (CO2, $\mathrm{CH}_{4}, \mathrm{H}_{2}$, noble gases) in clay interlayer nanopores." J. Phys. Chem. C, 121, pp.26539,2017.

[32]. A. Kongkanand and M. F. Mathias, "The priority and challenge of high-power performance of low-platinum protonexchange membrane fuel cells." J. Phys. Chem. Lett., 7, pp.1127, 2016.

[33]. A. Z. Weber and A. Kusoglu, "Unexplained transport resistances for low-loaded fuel-cell catalyst layers." J. Mater. Chem. A, 2, pp.17207, 2014.

[34]. A. Orfanidi, P. Madkikar, H. A. El-Sayed, G. S. Harzer, T. Kratky, and H. A. Gasteiger, "The key to high performance low Pt loaded electrodes." J. Electrochem. Soc., 164, pp. F418, 2017.

[35]. O. Gröger, H. A. Gasteiger, and J.-P. Suchsland, "Review-electromobility: batteries or fuel cells?" J. Electrochem. Soc., 162, pp. A2605, 2015.

[36]. V. Yarlagadda et al., "Boosting fuel cell performance with accessible carbon mesopores." ACS Energy Lett., 3, pp. 618, 2018. 